\title{
Utilization of Wood Vinegar as a Natural Preservative for Sengon Wood (Falcataria moluccana Miq.) against Fungal Attack (Schizophyllum commune Fries)
}

\author{
Riana Anggraini*, Jauhar Khabibi, Muhammad Rasyidur Ridho \\ Faculty of Agriculture, Jambi University. Jl. Raya Jambi-Muara Bulian KM 15, Mendalo Darat, 36361, Jambi, Indonesia \\ *Corresponding author. E-mail address: nanuk_onra@yahoo.co.id
}

ARTICLE HISTORY

Received: 8 March 2021

Peer review completed: 26 March 2021 Received in revised form: 6 April 2021 Accepted: 9 April 2021

\section{KEYWORDS}

Falcataria moluccana Wood durability

Wood parts

Wood vinegar

\begin{abstract}
Most wood supplied from forests currently has a low level of durability and vulnerable to wood-destroying organisms attacks. Sengon wood (Falcataria moluccana Miq.) is classified as low durable class wood (class IV-V); hence wood preservation is needed to protect from the attacks of wood-destroying organisms. One of the eco-friendly materials that can be used for wood preservation is wood vinegar. This study aims to analyze the influence of wood vinegar from tembesu (Fagraea fragrans) and rengas (Gluta renghas) on the durability of sengon wood against Schizophyllum commune Fries fungus. The results showed that wood parts and types of wood vinegar significantly affected preservative retention, absorption, penetration, and weight loss. Some of the chemical compounds contained in tembesu and rengas wood vinegar can inhibit the growth of fungi: (1) acetic acid (CAS) ethylic acid, (2) 2-propanone, 1-hydroxy(CAS) acetol, (3) phenol, 2-methoxy- (CAS) guaiacol, and (4) phenol (CAS) izal. Preservation of wood using tembesu and rengas wood vinegar with a concentration of $70 \%$ could increase the resistance of sengon wood and improve sengon wood's durability into very resistant (durability class I) against $S$. commune fungus attacks.
\end{abstract}

(C) 2021 The Author(s). Published by Department of Forestry, Faculty of Agriculture, University of Lampung in collaboration with Indonesia Network for Agroforestry Education (INAFE).

This is an open access article under the CC BY-NC license:

https://creativecommons.org/licenses/by $\mathrm{nc} / 4.0 \%$

\section{Introduction}

Most wood harvested from forests currently has a low durability and strength (Hutabarat et al. 2019). In Indonesia, the supply of low-durability woods reaches 80-85\% (Yunasfi 2008). Sengon (Falcataria moluccana Miq.) is one of the fast-growing wood species that have low durability. The wood can be used as crate-making materials, insulating boards, plywood, carpentry wood, and household furniture (Hardiatmi 2010). Sengon is classified as low durable class wood (class IV-V), and it is very susceptible to the attack of fungi, termites, and other wood-destroying organisms (Utari et al. 2018). Therefore, wood preservation is needed to protect sengon wood from wood-destroying organisms attacks. Until now, wood preservation commonly used synthetic chemicals. These chemicals can harm the environment and are also dangerous for humans (Utari et al. 2018). So, an alternative eco-friendly wood preservative is needed, such as wood vinegar (Ulfah et al. 2016). Previous research has reported that wood vinegar can prevent the attack of 
wood-destroying organisms, so it is very potential as a wood preservative (Orahmi et al. 2018; Setiawati 2010).

Wood vinegar is an organic liquid, yellow to blackish-brown in color, and has a strong smell. Wood vinegar contains several chemical components grouped into acetic acid, organic, phenolic acid, alkane, alcohol, and ester compounds (Jothityangkoon et al. 2008). Wood vinegar can be obtained from pyrolysis of sawn wood waste. The high quality of wood vinegar can be obtained from hardwood wastes (Sudarnyoto et al. 2014). In this study, hardwood species as tembesu (Fagraea fragrans) and rengas (Gluta renghas) were used to produce wood vinegar via the carbonization method. This study aims to determine the effect of wood vinegar application on the durability of sengon against Schizophyllum commune Fries fungus attacks. This study used a preservative concentration of $70 \%$, based on the previous study results (Setiawati 2010). Setiawati (2010) reported that a concentration of $70 \%$ could increase the resistance of rattan from Dinoderus minutus Farb attacks.

\section{Materials and Methods}

\subsection{Materials}

The material used was a 5-year-old sengon wood (Falcataria moluccana Miq.), which taken from the community garden of Kumpeh Ulu Subdistrict, Muaro Jambi Regency, Jambi Province, with the diameter, total height, and branch-free height were $22 \mathrm{~cm}, 12 \mathrm{~m}$, and $6.2 \mathrm{~m}$, respectively. The wood samples were obtained from the bottom, middle, and top, with a size of $5 \mathrm{~cm} \mathrm{x} 2.5 \mathrm{~cm}$ $x 1.5 \mathrm{~cm}$ (length $\mathrm{x}$ width $\mathrm{x}$ thickness) without skin (BSN 2006). The manufacture of wood vinegar used tembesu (Fagraea fragrans) and rengas (Gluta renghas) sawdusts from a sawmill of the Jambi City. This study was used the pure culture of mushrooms from the type of Schizophyllum commune Fries, Potato Dextrose Agar (PDA), distilled water, 70\% alcohol, cotton, tissue, and aluminum foil.

\subsection{Methods}

\subsubsection{Production of wood vinegar and wood preservation}

Wood vinegar from tembesu and rengas sawdusts were produced using the carbonization method by heating the sawdusts in the absence of oxygen. Sawdusts from each wood species were prepared and weighed about $1 \mathrm{~kg}$, then put into a charcoal furnace at a burning temperature of 200$300^{\circ} \mathrm{C}$ for $2 \mathrm{~h}$ with a pressure of $1 \mathrm{~atm}$ (Sudarnyoto et al. 2014). The initial concentration of wood vinegar produced using the furnace is assumed to be $100 \%$ pure without any other additives. A concentration of $70 \%(M 2$, in \%) was made by adding distilled water at the initial concentration $(M 1$, in $\%)$ and the initial volume $(V 1$, in $\mathrm{ml})$ to the desired volume $(V 2$, in $\mathrm{ml})$ using the following formula:

$M 1 \times V 1=M 2 \times V 2$

Sengon wood preservation was carried out by cold soaking. The sample was then put in a wood vinegar solution for $48 \mathrm{~h}$, with the entire surface of the sample immersed in preservative solution. 


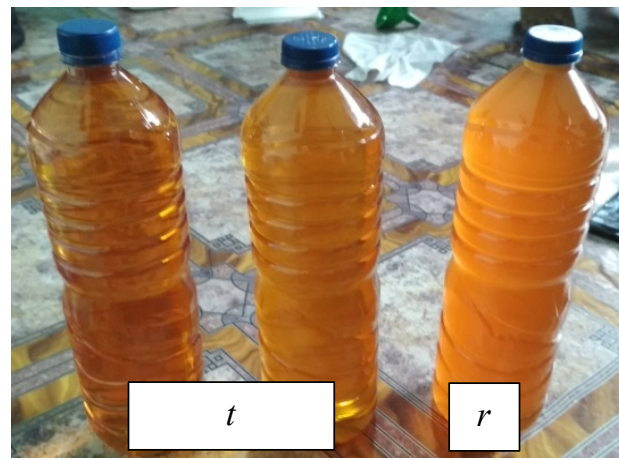

(a)

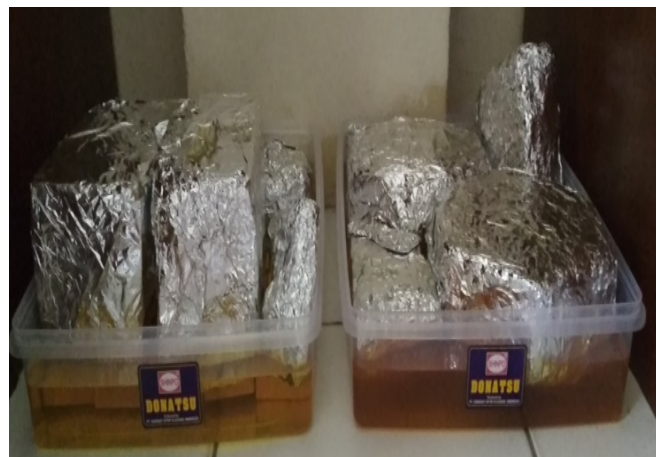

(b)

Fig. 1. (a) Wood vinegar from tembesu $(t)$ and rengas $(r)$, and (b) preservation of the samples.

\subsubsection{Schizophyllum commune Fries fungus isolation and feeding}

The method of $S$. commune fungus breeding and feeding was referred to the Ramadhani (2006) and performed using PDA media with a composition of $200 \mathrm{~g}$ of potatoes, $20 \mathrm{~g}$ of glucose, and $15 \mathrm{~g}$ of agar in $1,000 \mathrm{ml}$ water. The fungus culture filled the petri dish was then propagated by inoculating it into a glass bottle containing PDA media. The sample that has been soaked in wood vinegar solution was then fed to the glass bottle filled with $S$. commune fungus and stored in a glass cabinet at room temperature $\left(25^{\circ} \mathrm{C}\right)$ with a relative humidity of $79 \%$. The feeding was carried out for 12 weeks.

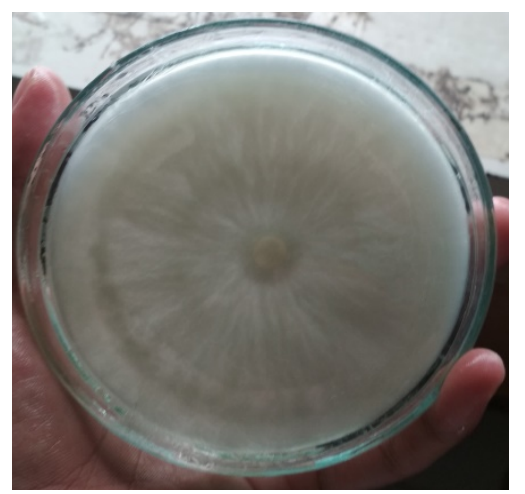

Fig. 2. Schizophyllum commune Fries fungal hyphae.

\subsubsection{The wood testing after treatment}

The moisture content (MC) can be calculated using a sample of wood before preserving it. Calculation of $\mathrm{MC}$ was carried out using air-dry weight $(A D$, in $\mathrm{g})$ and oven-dry weight $(O D$, in $\mathrm{g})$. $\mathrm{MC}$ was calculated using the following equation:

$$
M C(\%)=\frac{A D-O D}{O D} \times 100 \%
$$

\subsubsection{Preservative retention}

The retention measurement was conducted to determine the amount of preservative remains in the wood. Preservative retention was measured by weighing wood samples before and after preservation and calculated using the following equation:

$$
\text { Retention }\left(\mathrm{g} / \mathrm{cm}^{3}\right)=\frac{W A-W B}{V A} \times C
$$


where $W A$ is the weight after preservation $(\mathrm{g}), W B$ is the weight before preservation $(\mathrm{g}), V A$ is the volume after preservation $\left(\mathrm{cm}^{3}\right)$, and $C$ is the preservative concentration.

\subsubsection{Preservatives absorption}

Absorption is the amount of preservative solution that enters and seeps into the wood. The higher absorption of preservatives has a better protective effect against wood-destroying organisms. Preservative absorption preservation is calculated using the following equation:

$$
\text { Absorption }\left(\mathrm{g} / \mathrm{cm}^{3}\right)=\frac{W A-W B}{V B}
$$

where $W A$ is the weight after preservation $(\mathrm{g}), W B$ is the weight before preservation $(\mathrm{g})$, and $V B$ is volume before preservation $\left(\mathrm{cm}^{3}\right)$.

\subsubsection{Preservative penetration materials}

The preservative penetration is the depth of penetration of the preservative into the wood, expressed in $\mathrm{mm}$ or percent. The preservative penetration is calculated by measuring the color change caused by the preservative (Sumedi et al. 2011). The four sides of the cross-section of samples were measured using a caliper, and the average penetration of each sample was obtained.

\subsubsection{Weight reduction}

The weight reduction was calculated after feeding the wood samples to the pure fungus culture. The samples were cleaned and oven-dried at $60^{\circ} \mathrm{C}$ for $48 \mathrm{~h}$. The samples were then weighed to get the final weight. The percentage reduction in wood weight was calculated using the following equation:

$$
\text { Weight reduction }(\%)=\frac{W_{1}-W_{2}}{W_{1}} \times 100 \%
$$

where $W_{l}$ is the initial weight of the sample after oven-dried at $60^{\circ} \mathrm{C}$ for $48 \mathrm{~h}(\mathrm{~g})$, and $W_{2}$ is the final weight (after feeding) of the sample after oven-dried at $60^{\circ} \mathrm{C}$ for $48 \mathrm{~h}(\mathrm{~g})$.

\subsubsection{Wood vinegar characterization and GCMS analysis}

Characteristics testing was conducted by measuring the $\mathrm{pH}$ of wood vinegar, specific gravity, and color of wood vinegar, which is referred to the quality of Japanese wood vinegar (Yatagai 2002). Gas Chromatography-Mass Spectroscopy (GCMS) analysis was carried out at the Integrated Laboratory, the Islamic University of Indonesia, to determine the content of compounds in tembesu and rengas wood vinegar. The GCMS testing used the Shimadzu QP2010-SE at an ionization voltage of $70 \mathrm{eV}$ was conducted on an Rtx-5MS column contain Helium gas with a length of $30 \mathrm{~m}$, with a programmed temperature of $100^{\circ} \mathrm{C}$. The temperature was increased $10^{\circ} \mathrm{C}$ per minute to $250^{\circ} \mathrm{C}$ and held for 10 minutes. In addition, other parameters are ion source temperature of $250^{\circ} \mathrm{C}$, injection temperature of $250^{\circ} \mathrm{C}$, interface temperature of $250^{\circ} \mathrm{C}$, injection volume $1 \mu \mathrm{L}$, split ratio $1 / 153$, and mass susceptibility $\mathrm{m} / \mathrm{z}$ 30-600. The mass spectra data were compared with the Wiley and Nisti data libraries to obtain the names of compounds. The compound's name was observed from the presentation of the highest SI (spectra identification) value (Negoro 2007). 


\section{Result and Discussion}

\subsection{Moisture Content of Sengon Wood (Falcataria moluccana)}

Fig. 3 shows that the moisture content (MC) at the bottom, middle, and top of the sengon wood has almost the same value with $12.45-13.02 \%$. Hence, the sample used was very suitable for wood preservation treatment, where the condition of the $\mathrm{MC}$ for preservation generally is $12-18 \%$. Although, in this study, the MC between the bottom, middle, and top of the sengon wood was almost similar, sometimes the MC was different in the parts of the wood in one tree (bottom, middle, and top) (Qodariah 2007). The difference in MC is due to the ability of the wood cell walls to bind water (Rahayu 2018). The process of cell wall formation occurs at the bottom towards the middle and end of the stem. The cell wall at the bottom is thicker than the middle and top (Kailola et al. 2019). The MC of sengon wood is highly correlated with the preservative retention, absorption, and penetration because the MC of sengon wood is high, and it could prevent the entry of preservatives into the wood because the microvoid in the cell wall and cell cavity contains water (Usta 2004).

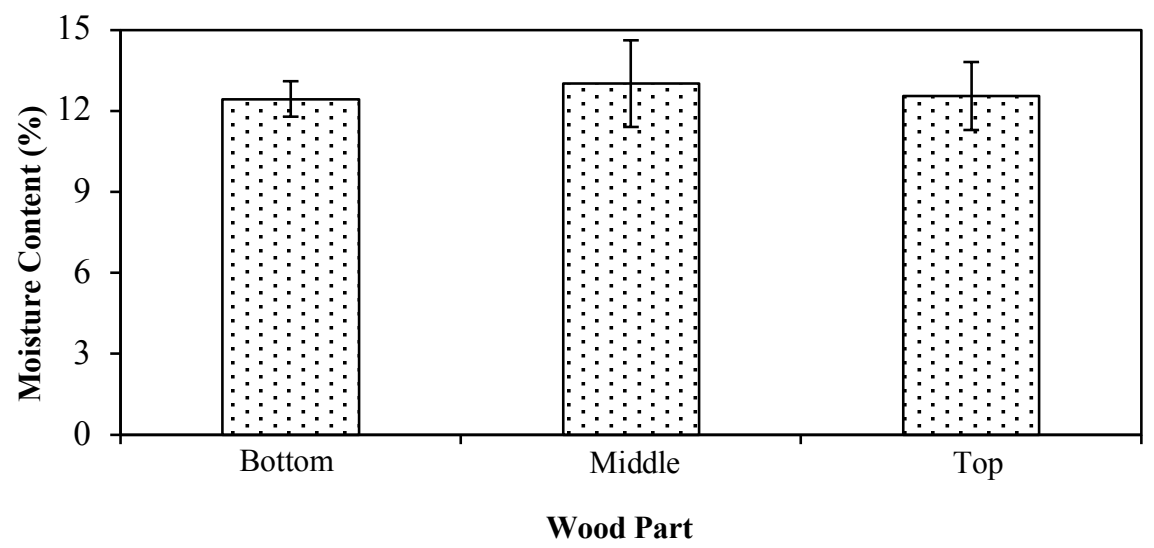

Fig. 3. The moisture content of sengon sengon wood ( $F$. moluccana).

\subsection{Preservative Retention Materials}

Preservative retention was calculated to determine the amount of preservative left in the wood (Kusumaningsih 2017). The success of preservation can be determined by the rate of preservative retention. The preservative retention of tembesu and rengas wood vinegar is presented in Fig. 4. The average preservative retention of tembesu wood vinegar was $0.012 \mathrm{~g} / \mathrm{cm}^{3}$, higher than the rengas wood vinegar of $0.010 \mathrm{~g} / \mathrm{cm}^{3}$. The highest retention was obtained at the middle part of the sengon wood sample for both tembesu and rengas wood vinegar of $0.013 \mathrm{~g} / \mathrm{cm}^{3}$ and $0.011 \mathrm{~g} / \mathrm{cm}^{3}$, respectively (Fig. 4), while the lowest retention was obtained at the top-part samples for both tembesu and rengas wood vinegar of $0.011 \mathrm{~g} / \mathrm{cm}^{3}$ and $0.0085 \mathrm{~g} / \mathrm{cm}^{3}$, respectively. The difference occurred because each part of the wood has different cell cavities (Iswanto 2008). The preservative retention is related to the ability of the solution to fill cell cavities and the length of preservation time (Cahyana 2014). The MC of sengon wood also influences preservative retention. Higher MC cause preservative difficult to enter cell cavities and remain in the wood (Usta 2004). 


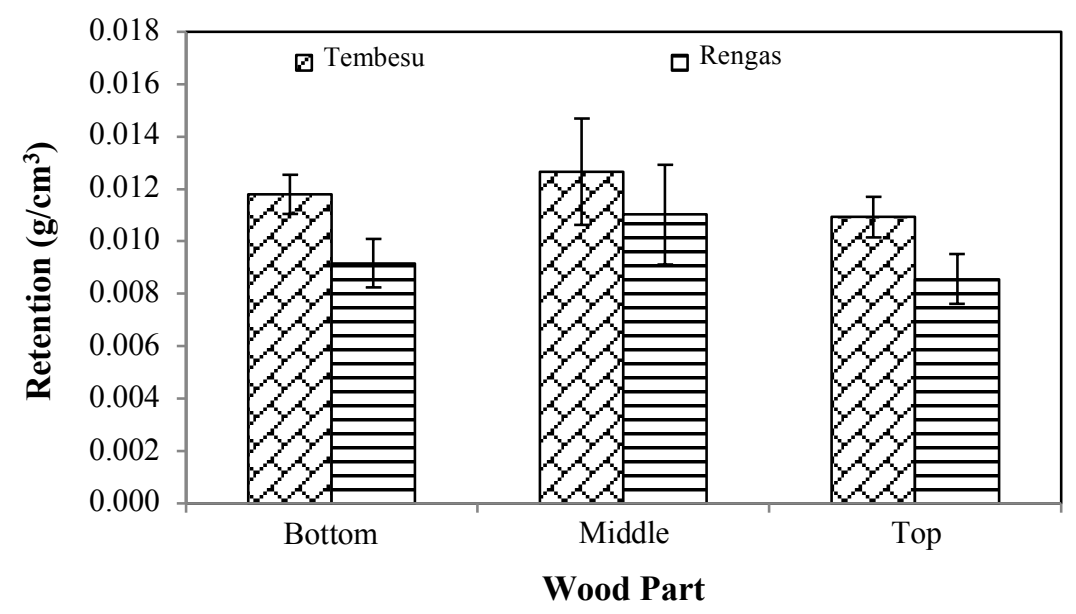

Fig. 4. The preservative retention of tembesu and rengas wood vinegar.

\subsection{Preservative Absorption}

Preservative absorption is the amount of preservative that enters and seeps into wood. The high preservative absorption indicates a more protective effect against wood-destroying organisms. The preservative absorption of tembesu and rengas wood vinegar on the sengon wood is presented in Fig. 5. The highest preservative absorption was obtained in the tembesu wood vinegar with an average value of $0.018 \mathrm{~g} / \mathrm{cm}^{3}$, and the rengas wood vinegar was about $0.014 \mathrm{~g} / \mathrm{cm}^{3}$. Each wood part showed a different value. The highest absorption was obtained in the middle of tembesu and rengas wood vinegar with $0.019 \mathrm{~g} / \mathrm{cm}^{3}$ and $0.016 \mathrm{~g} / \mathrm{cm}^{3}$, respectively. The lowest absorption value was obtained at the top with values of $0.016 \mathrm{~g} / \mathrm{cm}^{3}$ and $0.013 \mathrm{~g} / \mathrm{cm}^{3}$ in the sample treated with tembesu and rengas wood vinegar. The higher absorption of preservatives shows a better protective effect on wood against wood-destroying organisms (Kusumaningsih 2017). According to Kusumaningsih (2017), the lower the density of wood indicated the higher proportion of cell cavity volume, so that the preservative solution will be easier to enter into the wood. The $\mathrm{MC}$ in sengon wood correlates with absorption. Wood with a lower MC is easier to be penetrated by preservatives than wood with higher MC (Usta 2004).

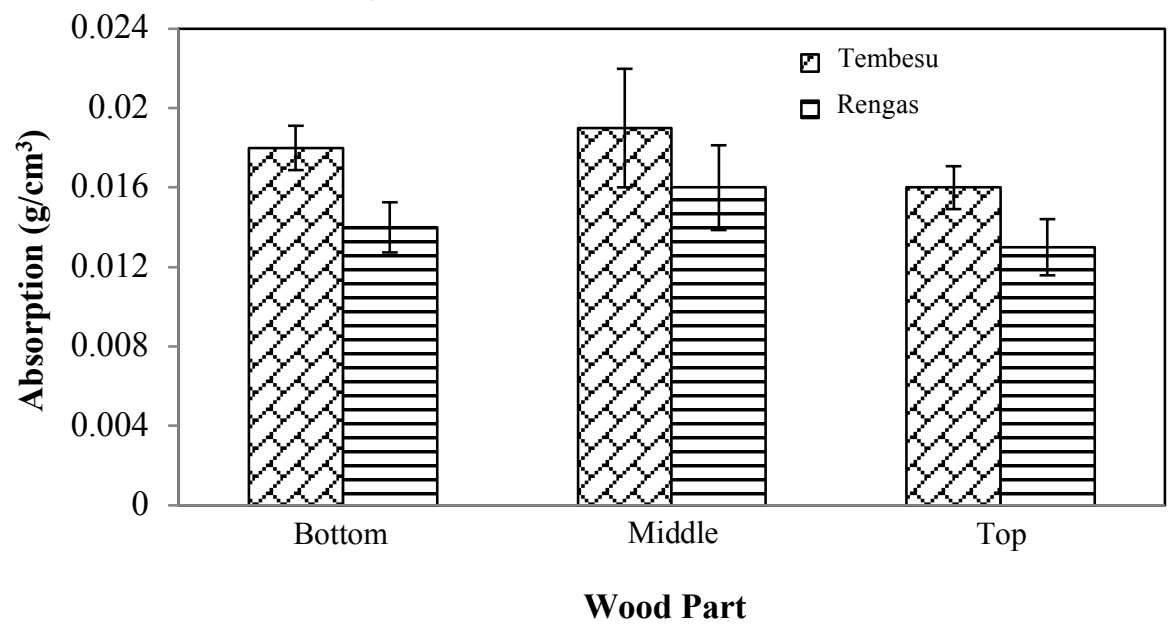

Fig. 5. The preservative absorption of tembesu and rengas wood vinegar. 


\subsection{Preservative Penetration}

The penetration of the preservative is the depth of penetration of the preservative into the wood. The preservation of wood will increase the depth of preservative that goes into the wood. Fig. 6 shows that the highest preservative penetration was obtained in tembesu wood vinegar with a value of $1.50 \mathrm{~mm}$, and the lowest is $0.87 \mathrm{~mm}$ in rengas wood vinegar. Each part of the wood had different values, showing the highest value at the top for both tembesu and rengas wood vinegar with the value of $1.57 \mathrm{~mm}$ and $1.53 \mathrm{~mm}$, while the lowest values were obtained at the bottom with a value of $1.39 \mathrm{~mm}$ for tembesu wood vinegar and $0.54 \mathrm{~mm}$ for rengas wood vinegar. This occurred because the top of the wood has a larger cell cavity than the bottom and middle (Sucipto 2009) so that the preservative easily enters the wood. The amount of penetration value is also influenced by the anatomical structure of the wood, MC, the type of preservative, and the method used (Pratiwi 2009). Wood with higher MC makes preservatives difficult to penetrate because the cell walls or cell cavities contain water (Usta 2004).

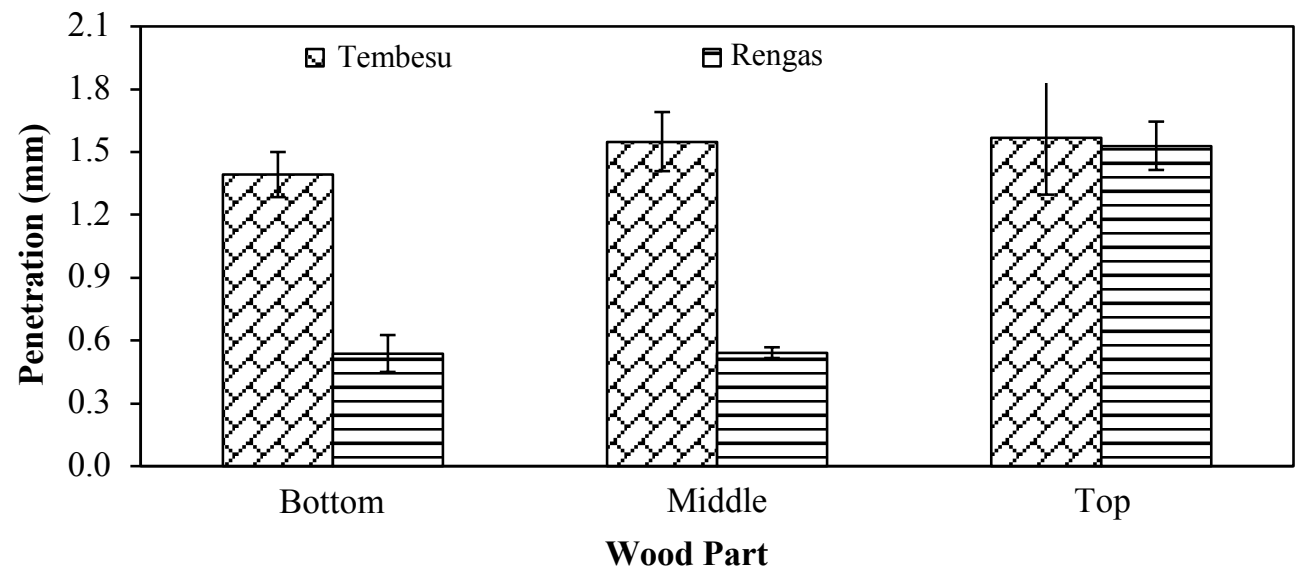

Fig. 6. The preservative penetration of tembesu and rengas wood vinegar.

\subsection{Weight Reduction}

The damage or weathering of wood can be indicated by the weight loss of the sample. The weight reduction in wood is due to the loss of some cellulose and lignin caused by the fungus (Syafitri 2008). Based on SNI 01.7207-2006, the sample on the three parts of wood without treatment (control) is included in the durability class IV (not resistant) with a weight reduction of $10-30 \%$. After preservation with tembesu and rengas wood vinegar on the three parts of the wood, it has increased to become durability class I (very resistant) with a weight loss of $\leq 1 \%$ (Fig. 7).

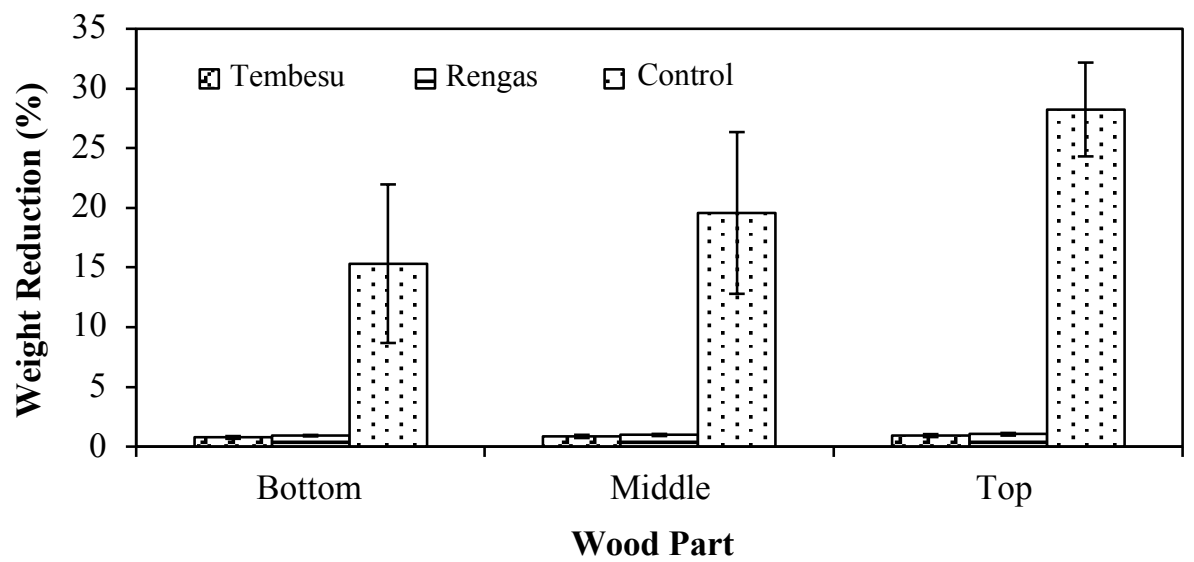

Fig. 7. Weight reduction of sengon wood after feeding test. 
The feeding results showed that the sample treated with the tembesu wood vinegar has the lowest weight reduction of $0.848 \%$, followed by rengas wood vinegar treatment of $0.975 \%$ and control of $21.046 \%$. At the bottom part, the lowest weight reduction value was obtained with $0.768 \%$ for the tembesu wood vinegar type, $0.918 \%$ rengas wood vinegar, and $15.322 \%$ control, while the top part was the part that obtained the highest weight reduction value, tembesu wood vinegar, vinegar rengas wood and control were $0.922 \%, 1,034 \%$, and $28,241 \%$, respectively. The weight reduction difference in the three wood parts is related to the different anatomical characteristics. The top part of the stem contains mostly juvenile wood cells (Purnawati et al. 2012), cause the wood-rot fungus easier to attack.

Visual observation of wood was carried out after the sample fed to the fungus culture for 12 weeks. The results of the untreated sample (control) observation indicated more fungal attack compared to the sample that was given the preservative of tembesu wood vinegar or rengas wood vinegar (Fig. 8a). The control sample indicated severe damage and experienced a change in color due to the attack of the white-rot fungus $S$. commune, compared to the treatment of the tembesu and rengas wood vinegar with no damage or significant color change (Fig. 8b). S. commune is a white-rot fungus from the Basidiomycetes class. This fungus can reduce holocellulose and lignin and altered wood color into yellowish, red-brown, or light brown color (Rahayu 2018). Herliyana et al. (2011) stated that $S$. commune fungus is quite malignant and can cause weight loss of up to $30 \%$.

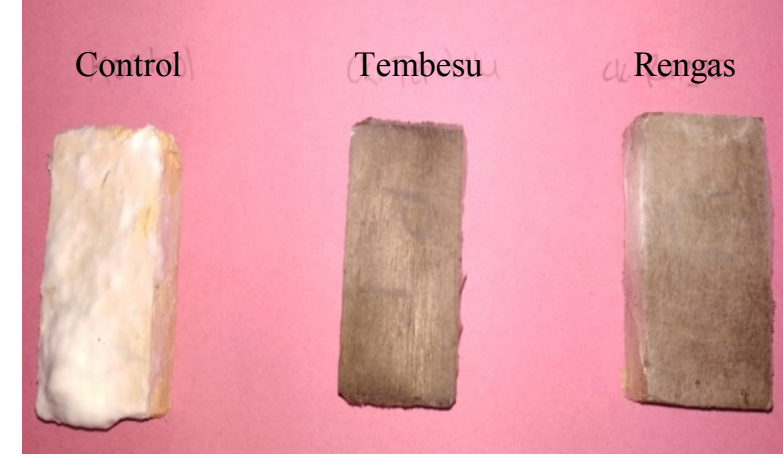

(a)

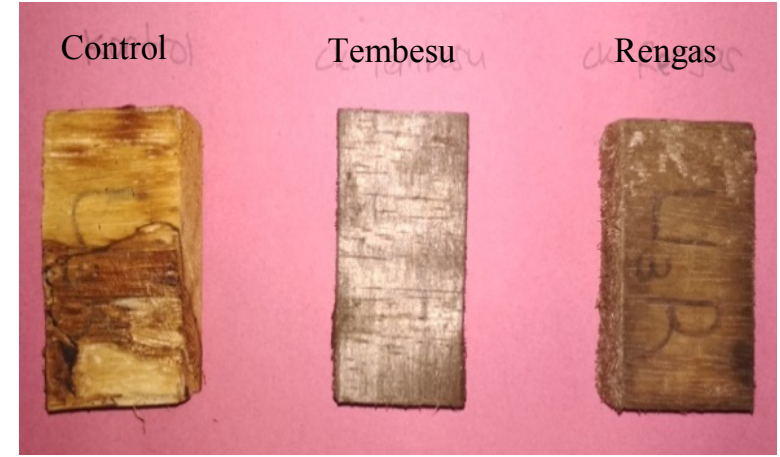

(b)

Fig. 8. Visual appearance of samples: (a) samples after 12 weeks, (b) samples after hyphae cleaning and oven-dry.

\subsection{Characteristics of wood vinegar and GCMS analysis}

The tembesu and rengas wood vinegar quality characteristics were tested to determine whether the wood vinegar produced is included in the quality standard of wood vinegar from Japan (Table 1). The $\mathrm{pH}$ of tembesu wood vinegar was 4.40, while the rengas wood vinegar was 3.73. The $\mathrm{pH}$ value of rengas wood vinegar obtained is close to the standard $\mathrm{pH}$ quality of Japanese wood vinegar with a range of 1.50-3.70 (Yatagai 2002). The better preservation shows the more acidic $\mathrm{pH}$ of wood vinegar. This is because acidic wood vinegar will increase the durability of wood against wood-destroying insects and wood rot fungus. The density of wood vinegar produced was 1.02 for tembesu wood vinegar, while the specific gravity for rengas wood vinegar was 1.01. The result of density is lower than the quality standard of Japanese wood vinegar, which is $>1.05$ (Yatagai 2002). The color of tembesu wood vinegar is yellow-brown, and rengas wood vinegar is 
yellow. Compared to the Japanese standards, the two types of wood vinegar include the Japanese wood vinegar quality standard, which is yellow-reddish brown.

Table 1. Characteristics of the wood vinegar quality

\begin{tabular}{lccc}
\hline \multirow{2}{*}{ Type of analysis } & \multicolumn{2}{c}{ Type of wood vinegar } & Japanese wood vinegar \\
\cline { 2 - 3 } & Tembesu & Rengas & quality \\
\hline $\mathrm{pH}$ & 4.40 & 3.73 & $1.50-3.70$ \\
Density & 1.02 & 1.01 & $>1.05$ \\
Color & Yellow-brown & Yellow & Reddish yellow-brown \\
\hline
\end{tabular}

The chemical compound component of wood vinegar is a tested parameter, which aims to determine the active substance that acts as an antidote to the wood destroying organisms' attacks. GC-MS test results showed 10 compound peaks in tembesu wood vinegar, while for rengas wood vinegar was 9 compound peaks (Fig. 9). Each peak that appears on the chromatogram represents the type of compound contained in wood vinegar. Chemical compounds can be identified using Willey data by looking at the percent SI (spectra identification). The chemical compounds of tembesu and rengas wood vinegar are presented in Table 2.

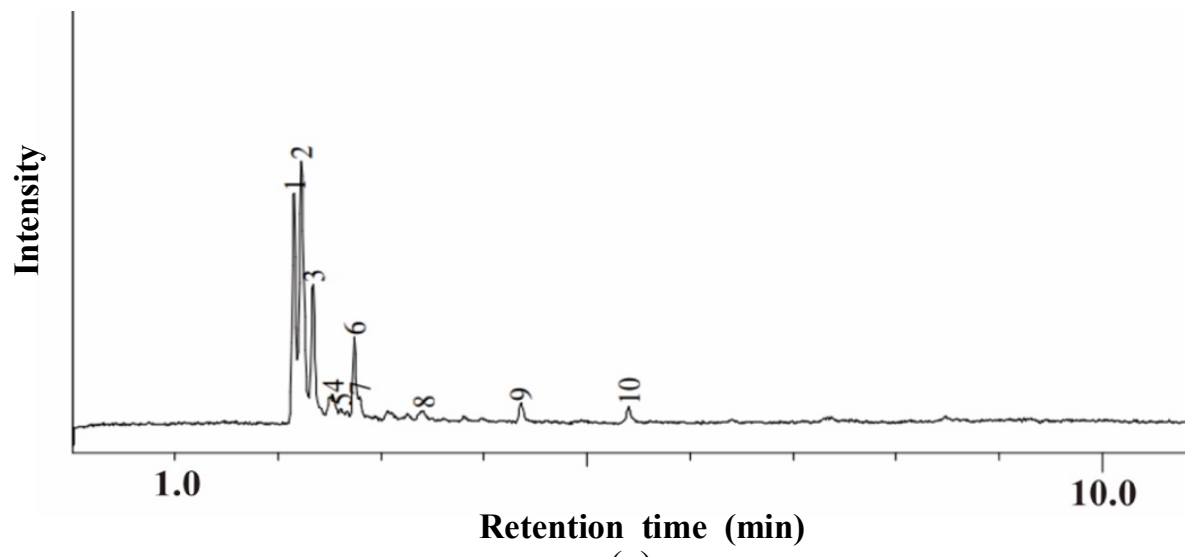

(a)

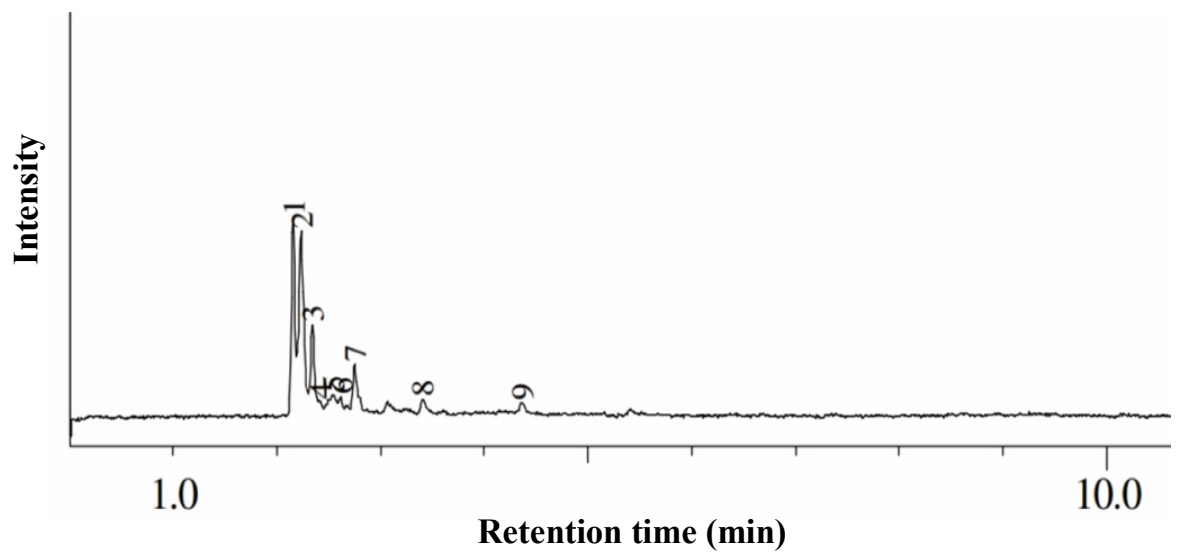

(b)

Fig. 9. The results of the GCMS test analysis, (a) tembesu wood vinegar, (b) rengas wood vinegar.

The results of reading Willey data from two types of wood vinegar have compounds that can inhibit fungal growth and termite attacks, such as the phenol group and its derivatives (Sumedi et 
al. 2011; Ulfah et al. 2016). The compounds that have the potential to inhibit fungi and termite attacks such as acetic acid (CAS) ethylic acid (35.62\% in tembesu wood vinegar and $37.69 \%$ in rengas wood vinegar), 2-propanone, 1-hydroxy- (CAS) acetol (17.28\% in tembesu wood vinegar and $13.51 \%$ in rengas wood vinegar), phenol 2-methoxy- (CAS) guaiacol (2.14\% in tembesu wood vinegar and $1.29 \%$ in rengas wood vinegar) and $2.41 \%$ phenol (CAS) izal compounds which are only found in rengas wood vinegar. From several sources of raw material for wood vinegar, the same compounds as tembesu and rengas wood vinegar are obtained, such as chemical components of wood vinegar from coconut shells, sengon wood-blocks, and mixed sawdust from natural forests and plantation forests, chemical compounds are found including acetic acid (CAS) ethylic acid, phenol (CAS) izal, phenol, 2-methoxy- (CAS) guaiacol, 2-propanone, 1-hydroxy- (CAS) acetol, O-creosol, P-creosol, furfural, A-methyl guaiacol, cyclohexane, propanoic acid (CAS), and furancarbon sacurichlorid, tetrahydro (Komarayati et al. 2011; Nurhayati et al. 2006; Sumedi et al. 2011). Phenolic compounds including phenol izal, guaiacol, hydroxyl, and propanone, are predicted to act as antioxidants so that they can extend the shelf life of smoke products, while acidic compounds such as acetic acid and ethylic acid have an antibacterial role (Sumedi et al. 2011).

Table 2. The chemical compounds of tembesu and rengas wood vinegar.

\begin{tabular}{|c|c|c|c|c|c|c|}
\hline \multirow[b]{2}{*}{ Peak } & \multicolumn{6}{|c|}{ Compounds } \\
\hline & Tembesu wood vinegar & $\begin{array}{l}\text { Area } \\
(\%)\end{array}$ & $\begin{array}{c}\text { Chemical } \\
\text { formula }\end{array}$ & Rengas wood vinegar & $\begin{array}{l}\text { Area } \\
(\%)\end{array}$ & $\begin{array}{l}\text { Chemical } \\
\text { formula }\end{array}$ \\
\hline 1 & Methanol (CAS) carbinol & 22.71 & $\mathrm{CH}_{4} \mathrm{O}$ & Methanol (CAS) carbinol & 25.59 & $\mathrm{CH}_{4} \mathrm{O}$ \\
\hline 2 & $\begin{array}{l}\text { Acetic acid (CAS) Ethylic } \\
\text { acid }\end{array}$ & 35.62 & $\mathrm{C}_{2} \mathrm{H}_{4} \mathrm{O}_{2}$ & $\begin{array}{l}\text { Acetic acid (CAS) ethylic } \\
\text { acid }\end{array}$ & 37.68 & $\mathrm{C}_{2} \mathrm{H}_{4} \mathrm{O}_{2}$ \\
\hline 3 & $\begin{array}{l}\text { 2-propanone, 1-hydroxy- } \\
\text { (CAS) acetol }\end{array}$ & 17.28 & $\mathrm{C}_{3} \mathrm{H}_{6} \mathrm{O}_{2}$ & $\begin{array}{l}\text { 2-propanone, 1-hydroxy- } \\
\text { (CAS) acetol }\end{array}$ & 13.51 & $\mathrm{C}_{3} \mathrm{H}_{6} \mathrm{O}_{2}$ \\
\hline 4 & 1-hydroxy-2-butanone & 6.07 & $\mathrm{C}_{4} \mathrm{H}_{8} \mathrm{O}_{2}$ & $\begin{array}{l}\text { Propane, 2-ethoxy- (CAS) } \\
\text { ethyl isopropyl ether }\end{array}$ & 2.03 & $\mathrm{C}_{5} \mathrm{H}_{12} \mathrm{O}$ \\
\hline 5 & $\begin{array}{l}\text { Cyclopentanone (CAS) } \\
\text { dumasin }\end{array}$ & 1.56 & $\mathrm{C}_{5} \mathrm{H}_{8} \mathrm{O}$ & $\begin{array}{l}\text { 3-furanol, tetrahydro- } \\
\text { (CAS) 3- }\end{array}$ & 5.81 & $\mathrm{C}_{4} \mathrm{H}_{8} \mathrm{O}_{2}$ \\
\hline 6 & $\begin{array}{l}\text { 2-furancarboxaldehyde } \\
\text { (CAS) furfural }\end{array}$ & 8.66 & $\mathrm{C}_{5} \mathrm{H}_{4} \mathrm{O}_{2}$ & $\begin{array}{l}\text { Hydroxytetrahydrofuran } \\
\text { cyclopentanone (CAS) } \\
\text { dumasin }\end{array}$ & 2.15 & $\mathrm{C}_{5} \mathrm{H}_{8} \mathrm{O}$ \\
\hline 7 & $\begin{array}{l}\text { 2-butanone (CAS) methyl } \\
\text { ethyl ketone }\end{array}$ & 2.39 & $\mathrm{C}_{4} \mathrm{H}_{8} \mathrm{O}$ & $\begin{array}{l}\text { 2-furancarboxaldehyde } \\
\text { (CAS) furfural }\end{array}$ & 9.53 & $\mathrm{C}_{5} \mathrm{H}_{4} \mathrm{O}_{2}$ \\
\hline 8 & $\begin{array}{l}\text { Ethanone, 1-(1H-pyrrol-2- } \\
\text { yl)- (CAS) 2-acetylpyrrole }\end{array}$ & 1.68 & $\mathrm{C}_{6} \mathrm{H}_{7} \mathrm{NO}$ & Phenol (CAS) izal & 2.41 & $\mathrm{C}_{6} \mathrm{H}_{6} \mathrm{O}$ \\
\hline 9 & $\begin{array}{l}\text { Phenol, 2-methoxy- (CAS) } \\
\text { guaiacol }\end{array}$ & 2.14 & $\mathrm{C}_{7} \mathrm{H}_{8} \mathrm{O}_{2}$ & $\begin{array}{l}\text { Phenol, 2-methoxy- } \\
\text { (CAS) guaiacol }\end{array}$ & 1.29 & $\mathrm{C}_{7} \mathrm{H}_{8} \mathrm{O}_{2}$ \\
\hline 10 & $\begin{array}{l}\text { 2-methoxy-4- } \\
\text { methylphenol }\end{array}$ & 1.89 & $\mathrm{C}_{8} \mathrm{H}_{10} \mathrm{O}_{2}$ & - & & \\
\hline
\end{tabular}

\section{Conclusions}

Wood vinegar from tembesu and rengas could increase the resistance of sengon wood against $S$. commune fungus attacks. The durability of sengon wood treated with tembesu and rengas wood vinegar was increased and classified as very resistant (durability class I), compared to the untreated sengon wood that classified as not resistant (durability class IV). Tembesu and rengas wood 
vinegar contained several compounds that could inhibit fungal growth, such as acetic acid (CAS) ethylic acid, 2-propanone, 1-hydroxy- (CAS) acetol, phenol, 2-methoxy- (CAS) guaiacol, and phenol (CAS) izal. The results suggested that tembesu and rengas wood vinegar can be developed as alternative wood preservatives.

\section{Acknowledgments}

The authors would like to thank the Forestry Study Program, Faculty of Agriculture, Jambi University, for helping to complete this research.

\section{References}

BSN. 2006. SNI 01-7207-2006: Uji Ketahanan Kayu dan Produk Kayu terhadap Organisme Perusak Kayu. Badan Standardisai Nasional (BSN). Jakarta, Indonesia.

Cahyana, B. T. 2014. Retensi dalam Pengawetan Kayu Kurang Dikenal untuk Bahan Baku Kapal Tradisional. Jurnal Riset Industri Hasil Hutan 6(2): 23-30. DOI: 10.24111/jrihh.v6i2.1234

Hardiatmi, J. M. S. 2010. Investasi Tanaman Kayu Sengon dalam Wanatani Cukup Menjanjikan. INNOFARM: Jurnal Inovasi Pertanian 9(2): 17-21.

Herliyana, E. N., Maryam, L. F. and Hadi, Y. S., 2011. Schizophyllum commune Fr. Sebagai Jamur Uji Ketahanan Kayu Standar Nasional Indonesia pada Empat Jenis Kayu Rakyat: Sengon (P. falcataria), Karet (H. brasiliensis), Tusam (P. merkusii), Mangium (A. mangium). Jurnal Silvikultur Tropika 2(3): 176-180.

Hutabarat, F. V., Diba, F., and Sisilia, L. 2019. Daya Hambat Ekstrak Kulit Jati (Tectona grandis Linn F) terhadap Pertumbuhan Jamur Pelapuk Kayu Schizophyllum commune Fries. Jurnal Hutan Lestari 7(3): 1078-1089. DOI: 10.26418/jhl.v7i3.36433

Iswanto, A. H. 2008. Sifat Fisik Kayu: Berat Jenis dan Kadar Air pada Beberapa Jenis Kayu. Skripsi. Universitas Sumatera Utara. Medan, Indonesia.

Jothityangkoon, D., Koolachart, R., Wanapat, S., Wongkaew, S., and Jogloy, S. 2008. Using Wood Vinegar in Enhancing Peanut Yield and in Controlling the Contamination of Aflatoxin Producing Fungus. International Crop Science 4: 253-253.

Kailola, J., Simanjuntak, R., and Punyia, K., 2019. Kandungan Kadar Air $\left(\mathrm{H}_{2} \mathrm{O}\right)$ dari Jenis Kayu Jati (Tectona grandis) dan Kayu Sengon (Paraserianthes falcataria) Asal Tobelo Kabupaten Halmahera Utara. Agrikan: Jurnal Agribisnis Perikanan 12(2): 311-316. DOI: 10.29239/j.agrikan.12.2.311-316

Komarayati, S., Gusmailina, and Pari, G. 2011. Produksi Cuka Kayu Hasil Modifikasi Tungku Arang Terpadu. Jurnal Penelitian Hasil Hutan 29 (3): 234- 247. DOI: 10.20886/jphh.2011.29.3.234-247

Kusumaningsih, K. R. 2017. Sifat Penyerapan Bahan Pengawet pada Beberapa Jenis Kayu Bangunan. Jurnal Wana Tropika 16-25.

Negoro, A. M. 2007. Penentuan Metode Terbaik Proses Penyulingan Minyak Atsiri Daun Sirih (Piper betl LINN.) antara Penyulingan dengan Air dan Penyulingan dengan Air dan Uap. Skripsi. Universitas Sanata Dharma. Yogyakarta, Indonesia.

Nurhayati, T., Pasaribu, R. A., and Mulyadi, D. 2006. Produksi dan Pemanfaatan Arang dan Cuka Kayu dari Serbuk Gergaji Kayu Campuran. Jurnal Penelitian Hasil Hutan 24(5): 395-411. DOI: 10.20886/jphh.2006.24.5.395-411 
Oramahi, H. A., Yoshimura, T., Diba, F., Setyawati, D., and Nurhaida. 2018. Antifungal and Antitermitic Activities of Wood Vinegar from Oil Palm Trunk. Jurnal of Wood Science 64: 311-317. DOI: 10.1007/s10086-018-1703-2

Purnawati, R., Wahyudi, I., and Priadi, T. 2012. Anatomical Properties of Flindersia pimenteliana F. Muell from Wondama Bay West Papua. Jurnal Ilmu dan Teknologi Kayu Tropis 10(2): 122-129.

Pratiwi, G. A. 2009. Sifat Keawetan dan Pengawetan Beberapa Jenis Kayu Rakyat. Skripsi. Institut Pertanian Bogor. Bogor, Indonesia.

Qodariah, M. T. 2007. Penurunan Kadar Air Kayu Mangium (Acacia mangium Willd.) dengan Peneresan dan Pengeringan menggunakan FAN. Skripsi. Bogor (ID); Institut Pertanian Bogor

Rahayu, Y. C. 2018. Variasi radial keawetan kayu eboni (Diospyros celebica Bakh.) terhadap rayap kayu kering dan jamur Schizophyllum commune. Skripsi. Institut Pertanian Bogor. Bogor, Indonesia.

Ramadhani, J. 2006. Peningkatan Keawetan Kayu Gmelina arborea Roxb. dari Serangan Jamur Pelapuk dengan Bahan Pengawet Alami. Skripsi. Institut Pertanian Bogor. Bogor, Indonesia.

Setiawati, E. 2010. Daya Tahan Rotan yang Diawetkan dengan Cuka Kayu Galam terhadap Serangan Bubuk Dinoderus minutus Farb. Jurnal Riset Industri Hasil Hutan 2(2): 8-12. DOI: 10.24111 jrihh.v2i2.1141

Sucipto, T. 2009. Penentuan Air dalam Rongga Sel Kayu. Karya Tulis. Universitas Sumatera Utara. Medan, Indonesia.

Sudarnyoto, Johan, V. S., and Rahmayuni. 2014. Potential Wood Vinegar from Eucalyptus pellita and Acacia mangium Wild as Antimicrobial. Jurnal Online Mahasiswa Fakultas Pertanian 1(1): 1-9.

Sumedi, A., Budiarso, E., and Kusuma, I. W. 2011. Pemanfaatan Asap Cair dari Tempurung Kelapa sebagai Bahan Pengawet Kayu Karet (Hevea brasiliensis Muell.Arg.). Jurnal Kehutanan Tropika Humida 4(1): 1-12.

Syafitri, I. 2008. Biodeteriorasi Tiga Jenis Kayu Cepat Tumbuh oleh Jamur Pelapuk. Skripsi. Institut Pertanian Bogor. Bogor, Indonesia.

Ulfah, D., Lusyiana, and Harionarso, B. 2016. Pengaruh Lama Penyimpanan Cuka Kayu Gelam pada Pengawetan Kayu Karet (Hevea brasiliensis Muell. Arg.) terhadap Serangan Rayap. Jurnal Hutan Tropis 4(1): 21-27. DOI: 10.20527/jht.v4i1.2878

Usta, I. 2004. The Effect of Moisture Content and Wood Density on the Preservative Uptake of Caucasian Fir (Abies nordmanniana (Link.) Spach) treated with CCA. Turk J Agric For. 28: $1-7$.

Utari, N., Diba, F., and Sisillia, L. 2018. Perbandingan Tingkat Keawetan Kayu Sengon (Falcataria moluccana L. Nielesn) dan Kayu Sugi (Cryptomeria japonica D. Don) dengan Ekstrak Limbah Kulit Kayu Jati (Tectona grandis L.F.) terhadap Serangan Rayap Tanah Coptotermes curvignathus Holmgren. Jurnal Tengkawang 8(2): 75-87. DOI: $10.26418 /$ jt.v8i2.30893

Yatagai. 2002. Utilization of Charcoal and Wood Vinegar in Japan. Graduate School of Agricultural and Life Sciences. The University of Tokyo. Japan.

Yunasfi. 2008. Fungi at Eucalyptus urophylla S.t. Blake in Log Yard (TPK) PT. Toba Pulp Lestari, Tbk. Kabupaten Toba Samosir North Sumatera. Jurnal Hutan dan Masyarakat 3(1): 79-88. 